\title{
Effects of Mobile Augmented Reality and Self-Regulated Learning on Students' Concept Understanding
}

\author{
https://doi.org/10.3991/ijet.v15i22.16387 \\ Chusnul Muali $(\bowtie)$ \\ Universitas Negeri Malang, Malang, Indonesia \\ Universitas Nurul Jadid, Probolinggo, Indonesia \\ chusnulmualieunuja.ac.id \\ Punaji Setyosari, Purnomo, Lia Yuliati \\ Universitas Negeri Malang, Malang, Indonesia
}

\begin{abstract}
Several studies have shown an increase in students' interest towards implementing augmented reality. The majority of these studies focus on how this technology can affect student performance with various abilities and skills. Therefore, the purpose of this study is to examine differences in students understanding level after using mobile augmented reality and conventional learning based on their self-regulated learning levels in the solar system class. Data were obtained from 91 students, with 47 of them in the experimental group using mobile augmented reality, while the remaining 44 are in the control group using conventional learning. This study measured students' self-regulated learning ability using a four-point Likert scale and 2 multiple-choice questions. This result showed higher levels of concept understanding among students in the experimental group compared to the control. Furthermore, the results indicate the effect of the self-regulated learning level towards students' concepts understanding. It showed that students with high self-regulated learning levels had a different conceptual understanding from those with low self-regulated learning levels.
\end{abstract}

Keywords-Mobile Learning, Augmented Reality, Self-Regulated Learning, Students' Concept Understanding

\section{Introduction}

Mobile computing devices such as smartphones are currently used to provide positive contributions in learning. The smartphone also known as a mobile device as an instrument used to achieve learning goals irrespective of place and time[1]. Therefore, there is a need to adopt cellular technology in learning due to its capacity to attract and motivate students[2], providing an understanding and visualization of complex scientific reasoning[3]. Various studies have shown that this instructional technology encourages students to be directly involved in learning, influences performance, and motivation[4][5]. In addition, mobile learning has changed the educational paradigm effectively and flexibly. 
The presence of augmented reality provided numerous ways for students to comprehend scientific concepts. It can embrace digital information in a variety of media formats, thereby enabling students to learn summary concepts using $3 \mathrm{D}$ and geometric objects[6]. Augmented reality has a property to draw attention, which enables the association of virtual and reality, thereby ensuring adequate learning knowledge through experience, interest, and encouragement[7]. The offered learning proficiency comprises of many factors with augmented reality as a new development technology in education[8]. Therefore, augmented reality attends to promote the edutainment concept and increase students' participation substantially.

The concept of mobile augmented reality emerged since mid-1990 as an interface technology established by cellular settings, thereby, making it useable by the learning environment[9]. In this way, the learning procedure is easier, more efficient, and the concept is properly understood[10]. Liu et al.[11] and Abdallah et al.[12] reported that mobile augmented reality provides benefits used to motivate students' involvement in learning, and the ability to rectify learning outcomes and experiences and performed significantly better than those in achievements and visual thinking.

This proves that the education system is widely open to the online environment, although there are many factors to consider for further development of the learning process. Therefore, it is estimated that the involvement of students' self-regulated learning is needed. Some research stated that the self-regulated learning process is recognized as an important factor in student learning success. Barnard et al.[13] stated that students with high self-regulating abilities are skilled and academically better than those with low self-regulated learning. This is because they proactively find information and develop themselves to master it. Furthermore, they can overcome difficult situations by viewing learning acquisition as a systematic and controlled process, therefore, they accept responsibility for their own achievement[14].

Development of Mobile Augmented Reality Application

Augmented reality enables users to determine experiences in the real and virtual world environments simultaneously. Milgram and Kishino[15] stated that the continuums of augmented and virtual realities are shown in figure 1.

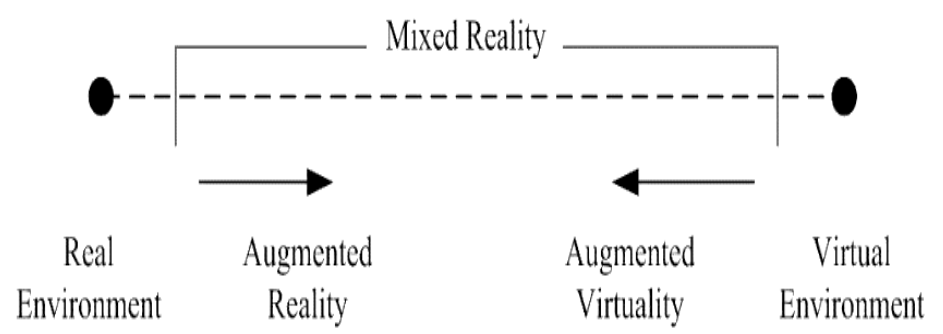

Fig. 1. Milgram Augmented Reality continuum

The situation in the two environments is called mixed reality, and it integrates digital information in a real environment. Augmented reality combines 2D and 3D object types with real-time interactions while reflecting mixed reality in the augmented 
continuous[16]. Users experience natural and real human-computer interaction with virtual objects placed in a real view[17].

Preliminary observations have been made regarding the use of tools and learning technology. It was found that augmented reality was developed based on markers, with the use of computer equipment as teaching material. This study adopted sural[6] using the Vuforia SDK and Unity tools to achieve good support and documentation. Unity and Vuforia plugin are used to develop learning material because it is one of the best development platforms for building high-quality 3D and 2D games. The main components used in the development process are shown in figure 2.

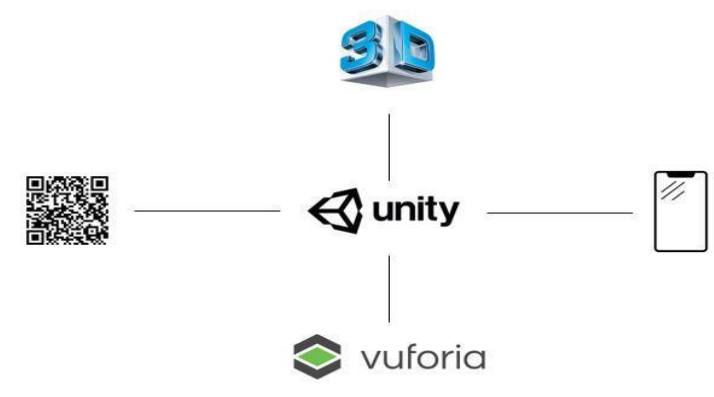

Fig. 2. Marker-based mobile Augmented Reality development process[6]

- 3D Models: This is the most important part of an augmented reality application. The quality and functionality of virtual objects such as video, text, or 3D computer models, affect the application. The first step in marker-based augmented reality design is developing a 3D model or video, with a link used to show when the camera is scanning markers[6].

- QR Code: QR code is an evolution of the barcode. It is a type of matrix code or twodimensional barcode with the main functionality readable by the scanner or smartphones and cellphones with cameras[18]. Initially, the QR code was used for tracking vehicle parts in manufacturing. QR codes are now used in a broader context, including commercial applications and the ease of tracking smartphone-oriented applications. The presence of this code allows the audience to interact through smartphones effectively and efficiently. QR codes have a smaller appearance than bar codes. QR code is able to accommodate data horizontally and vertically. Automatically, the size of the appearance of the QR code image can be only onetenth of the size of a barcode.

- Vuforia: Vuforia is an augmented reality (SDK) software development device for mobile devices. It uses computer vision technology to recognize and track 3D objects, being able to position and orient virtual objects, such as 3D models and other media with real objects when viewed through a mobile device's camera. Vuforia SDK supports various types of targets, including image targets, 3D models, and fiduciary marker shapes. It also allows developers to create augmented reality applications and games easily[19]. 
- Unity: Unity is an application for developing multi-platform games. Unity is fully integrated with professional applications. Unity graphics are high-level graphics for OpenGL and directX. Unity supports all file formats, especially common formats such as all formats of art applications. Unity is compatible with the 64-bit version and can operate on Mac OS $\mathrm{x}$ and windows and can produce games for Mac, Windows, Wii, iPhone, iPad and Android.

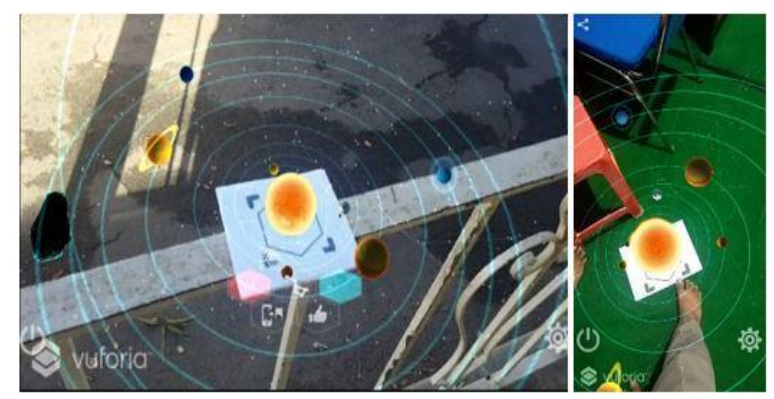

Fig. 3. Display augmented reality on mobile devices

\section{$2 \quad$ Method}

\subsection{Research design}

This study used a quasi-experimental design in the pretest and posttest nonequivalent control group. The study used an intact group to reduce the establishment of causal relationships due to the difficulty in randomly determining the subjects. There was no doubt on the equivalence groups before the experiment started[20]. The hypothesis tested in this study was the difference in students' mean scores of concept understanding. This was taught by using mobile-augmented reality based on selfregulated learning and those that learn without using mobile augmented reality.

\subsection{Participant}

Participants of this study involved the ninth-grade student of Pakuniran Probolinggo Public Middle School obtained through random cluster sampling. A total of 91 participants divided into the experimental group consisting of 47 students and the control group with 44 students.

\subsection{Instruments}

This research uses two types of research instruments:

Self-regulated learning: This instrument was developed by Onah \& Sinclair[21] through the MOOC online self-regulated questionnaire (MOSLQ), used to measure the 
dimensions of self-regulated learning. The study also used a 19 Likert scale items with a 4-point type, ranging from 4-always to 1-never to collect students' responses. Therefore, the research can be evaluated to answer the MOSLQ questions which were carried out using the following dimensions: Goal Settings (GS), the process where students set specific predetermined goals and plan, Task Strategies (TS), as students' ability to plan and strategize how to achieve set goals, Time Management (TM), as a dimension that involves the ability or skills of time management during learning, Environment Structuring (ES), as a learning dimension in an online or virtual environment, Help-Seeking (HS), as students ability to ask for help in their area of concern when studying online and Self-Evaluation (SE), as the process of reflecting student ability to understand the fields that have been achieved. One component in MOOC is the ability to collaborate and interact while learning, which are all aspects of discussion forums. Table 1 shows the 19 items of MOSLQ instrument questions.

Table 1. MOSLQ survey question

\begin{tabular}{|l|l|}
\hline GSQ1 & I know what to achieve in this study. \\
\hline GSQ2 & I have prepared myself to study in this class. \\
\hline GSQ3 & I have high standards in learning performance on this subject. \\
\hline GSQ4 & I have set targets to achieve success in this lesson. \\
\hline GSQ5 & I was not directly involved in this learning because it was carried out online. \\
\hline GSQ6 & I have written down my predetermine goals after this lesson. \\
\hline TSQ1 & I have a strategy to complete study assignments in order to achieve learning goals. \\
\hline TSQ2 & $\begin{array}{l}\text { I prepared myself by reading the available learning material before participating in this } \\
\text { study. }\end{array}$ \\
\hline TSQ3 & I set the study agenda before participating with online resources. \\
\hline TSQ4 & I am prepared to face the challenges associated with learning. \\
\hline TMQ1 & I have mapped out plans on how to spend a lot of time studying online. \\
\hline TMQ2 & I found the right time to study, to avoid distractions. \\
\hline ESQ1 & I chose a quite location (place) to avoid distractions while studying. \\
\hline ESQ2 & I found a convenient learning location. \\
\hline ESQ3 & I chose the right location to learn effectively. \\
\hline HSQ1 & $\begin{array}{l}\text { I plan to use the interactive communication channel in order to get support from peers and } \\
\text { teachers (tutors). }\end{array}$ \\
\hline HSQ2 & $\begin{array}{l}\text { I intend to actively participate in the discussion forum in order to acquire maximal learning } \\
\text { results. }\end{array}$ \\
\hline SEQ1 & When following this lesson, I intend to reflect on my studies in each module \\
\hline SEQ2 & I intend to be proactive in involving and reviewing progress in my chosen learning path \\
\hline
\end{tabular}

Concept understanding: This instrument was developed to determine students' concepts understanding during the study. It starts by making a grid based on the concept understanding indicators and learning objectives for grade IX students in Junior High Schools to fulfill the content and items validity. The content validity in this study consists of conformity with learning objectives as reflected by indicators, tests arranged in a clear and simple form, and suitability tests to measure the conceptual understanding level on Physics. A trial was carried out for students group considered to have the same characteristics as those used as research subjects to analyze the test items' validity, differentiation, and difficulty level.

This study utilized a conceptual understanding test in the form of multiple choices consisting of 27 items. Furthermore, 20 items out of the 27 were found to fulfill the 
empirical validity requirement. Subsequently, the test was carried out with content validity to ensure there were no unmeasured concepts. Based on the learning technology of experts and test result data, valid items to measure students' conceptual understanding are 20 from 27 compiled items.

\subsection{Data analysis}

This study analyzed the following data:

- The concept understanding between groups of students using conventional learning to examine mobile augmented reality.

- The concept understanding between groups of students with high and low levels of self-regulated learning.

- The interaction effect between mobile augmented reality learning and self-regulated learning towards students' concepts understanding, with data collected and analyzed using descriptive and variance analysis.

\section{Result}

\subsection{Improvements on students' concept understanding in experimental and control group}

This study aims to determine the implementation effect of augmented reality mobile applications in improving students' concept understanding. Table 2 shows the differences between the mean scores of concepts understanding at the pre-test and posttest stages.

Table 2. The differences between mean scores of concept understanding pretest and posttest

Paired Samples Statistics

\begin{tabular}{|l|c|c|c|c|}
\hline & Mean & N & Std. Deviation & Std. Error Mean \\
\hline Pretest & 69.89 & 91 & 5.238 & .549 \\
\hline Posttest & 79.35 & 91 & 4.413 & .463 \\
\hline
\end{tabular}

Paired Samples Test

\begin{tabular}{|c|c|c|c|c|c|c|c|c|}
\hline & \multicolumn{5}{|c|}{ Paired Differences } & \multirow{3}{*}{$\mathbf{t}$} & \multirow{3}{*}{ df } & \multirow{3}{*}{$\begin{array}{l}\text { Sig. (2- } \\
\text { tailed) }\end{array}$} \\
\hline & \multirow[t]{2}{*}{ Mean } & \multirow[t]{2}{*}{$\begin{array}{c}\text { Std. } \\
\text { Deviatio } \\
n\end{array}$} & \multirow[t]{2}{*}{$\begin{array}{l}\text { Std. } \\
\text { Error } \\
\text { Mean }\end{array}$} & \multicolumn{2}{|c|}{$\begin{array}{l}\text { 95\% Confidence } \\
\text { Interval of the } \\
\text { Difference }\end{array}$} & & & \\
\hline & & & & Lower & Upper & & & \\
\hline $\begin{array}{l}\text { Pretest - } \\
\text { Posttest }\end{array}$ & -9.462 & 5.214 & .547 & -10.547 & -8.376 & -17.311 & 90 & .000 \\
\hline
\end{tabular}

The findings show a significant difference in students' concepts understanding after learning using the augmented reality mobile application. The paired sample tests showed a significant increase in understanding the pretest and posttest concepts $(\mathrm{M}=$ $9,462, \mathrm{SD}=5,214)$ with a significant increase in $\mathrm{t}(90)$ at $-17,311$ with a significant 
below 0.05 . These findings indicate that the augmented reality mobile application is an effective learning tool in improving students' concept understanding.

\subsection{Differences in students' concept understanding based on self-regulated learning}

This study also tested the differences in students' concepts understanding with low and high self-regulated levels, as shown in table 3 .

Table 3. The differences students concept understanding based on self-regulated learning

Concept Understanding

\begin{tabular}{|l|c|c|c|c|c|}
\hline Self-regulated learning & $\mathbf{N}$ & Mean & Std. Deviation & Minimum & Maximum \\
\hline High & 44 & 81.36 & 3.889 & 72 & 87 \\
\hline Low & 47 & 77.47 & 4.059 & 70 & 86 \\
\hline Total & 91 & 79.35 & 4.413 & 70 & 87 \\
\hline
\end{tabular}

The findings show that the average score of students' concepts understanding with high and low self-regulated levels was 81.36 and 77.47, with a score difference of 3.89 at a significant $\mathrm{p}$ below 0.05 . The rejection conclusion of the null hypothesis indicates that students 'self-regulated learning causes differences in students' concept understanding. This is supported by the results of the pairwise comparisons, which act as outputs of estimated marginal means, as shown in table 4.

Table 4. The differences between mean scores of concept understanding based on selfregulated learning, Pairwise Comparisons.

Dependent Variable: Concept Understanding

\begin{tabular}{|l|c|c|c|c|c|}
\hline \multicolumn{1}{|c|}{ (I) SRL (J) SRL } & Mean & Std. & Sig & \multicolumn{2}{|c|}{$\mathbf{9 5 \%}$ Confidence Interval for Differencea } \\
\cline { 5 - 6 } & Difference (I-J) & Error & & Lower Bound & Upper Bound \\
\hline High low & $3.791^{*}$ & .661 & .000 & 2.476 & 5.105 \\
\hline Low high & $-3.791^{*}$ & .661 & .000 & -5.105 & -2.476 \\
\hline
\end{tabular}

\subsection{The influence of interaction students' concept understanding between mobile augmented reality and self-regulated learning}

Inter-subject effect test is interpreted as the interaction between learning with mobile augmented reality and self-regulated learning towards students' concepts understanding, as shown in table 5. 
Table 5. Test of between subject effects

Dependent Variable: Concept Understanding

\begin{tabular}{|l|c|c|c|c|c|c|}
\hline \multicolumn{1}{|c|}{ Source } & Type III Sum of Squares & df & Mean Square & F & Sig. & $\begin{array}{c}\text { Partial Eta } \\
\text { Squared }\end{array}$ \\
\hline Corrected Model & $889.560^{\mathrm{a}}$ & 3 & 296.520 & 29.886 & .000 & .508 \\
\hline Intercept & 571302.518 & 1 & 571302.518 & $5.758 \mathrm{E} 4$ & .000 & .998 \\
\hline MAR & 508.014 & 1 & 508.014 & 51.202 & .000 & .370 \\
\hline SRL & 326.117 & 1 & 326.117 & 32.869 & .000 & .274 \\
\hline MAR * SRL & 46.436 & 1 & 46.436 & 4.680 & .033 & .051 \\
\hline Error & 863.187 & 87 & 9.922 & & & \\
\hline Total & 574751.000 & 91 & & & & \\
\hline Corrected Total & 1752.747 & 90 & & & & \\
\hline
\end{tabular}

a. R Squared $=, 508$ (Adjusted R Squared $=, 491)$

According to table 5, a statistical F-value of 46,436 is significant at $p<0.05$ for interaction variables. This indicates that the null hypothesis is rejected without an interaction effect between mobile augmented reality and self-regulated learning assisted with concept understanding. In contrast, the hypothesis stated that there is an interaction effect between mobile augmented reality, and self-regulated learning assisted with concept understanding is accepted.

This research is strengthened by the F-value variables generated by partial eta squared for Mobile Augmented Reality (MAR) and Self-Regulated Learning (SRL) at $0.051>0.26$. Therefore it can be categorized as having strong interactions, which indicates that the research is in accordance with the actual situation[22]. Meanwhile, the adjusted R2 value generated by the model is 0.508 , which means that MAR and SRL can be used to explain variations in the dependent variable of concept understanding. This means that $50.8 \%$ of the variation in concept understanding can be explained by the variables of mobile augmented reality and self-regulated learning.

\section{Discussions and Conclusion}

There is an adequate need to use technology contribution in education to shift the old paradigm in learning. The technological role is associated with replacing paper sheets in conventional learning with digitalized teaching materials[23]. The use of mobile augmented reality in learning has eliminated the limitations of space and time, thereby increasing students' motivation and concept understanding[24], [25]. This is evident from the analysis results associated with concepts understanding with significant differences obtained from the pretest and posttest scores. Therefore, mobile augmented reality learning has a considerable influence in improving students' understanding of concepts during the learning process. This is shown from the significant differences in the paired sample test results for concept understanding between students in the experimental and the control groups. Those in the experimental group showed higher concept understanding scores using mobile augmented reality than those in the control group that utilized the conventional learning technique. These results are in line with a Sural study[6], which stated that augmented reality needs to be 
integrated into certain learning strategies, with further research carried out to determine the effectiveness of teaching and learning materials designed with augmented reality devices.

Teachers and students' responses in measuring the satisfaction level using mobile augmented reality are not included as the main objectives of this study. However, they performed a dynamic two-way interaction during the learning process and were motivated to achieve learning goals. This is in line with Ozdamli \& Hursen [26] research, which stated that prospective teachers are very enthusiastic in managing to learn using mobile augmented reality. Meanwhile, Tugun [27] stated that the use of augmented reality applications on some material and other subjects influences students' positive roles.

Teachers and students find it challenging to change the learning environment from conventional to integrated technology[28]. This is because the use of technology and mobile devices requires them to possess different perspectives on learning and teaching[29]. This study shows that the aspects of technological mastery are essential for effective time management. This research is in line with Papadakis et al.[30] study, which stated that the use of software for the development of daily routines makes a substantial contribution in accelerating student learning time and understanding.

Other empirical results obtained in this study are that students with high selfregulated learning can manage to learn independently while mastering the online tools. This research is in line with the study carried out by Albelbisi and Yusuf [31], which measures six main factors that influence students' self-regulated learning in an online environment. In this study, MOOC online self-regulated questionnaire (MOSLQ) was developed and used as an instrument to measure the students' self-regulated learning level. This research is in accordance with Kizilcec et al.[32] and Littlejohn et al.[33] studies, which stated that the significant influence of self-regulated learning is in elearning environments.

This research explained that concept understanding depends on students' level of self-regulated learning, which requires the online implementation of effective elearning strategies[34]. The pairwise comparisons test results were used to determine the different levels of students' concepts understanding with variations between their high and low self-regulated learning. This study is in line with Cho and Shen[35] research, which stated that students with high self-regulated learning can learn independently. Therefore, their ability to successfully learn online is greater[36].

\section{Acknowledgement}

This research was supported by the Ministry of Religious Affairs (MORA) Republic of Indonesia. 


\section{References}

[1] A. Kukulska-Hulme and J. Traxler, "Design principles for mobile learning," Rethink. Pedagog. a Digit. Age Des. 21st Century Learn., pp. 244-257, 2013, doi: $10.4324 / 9780203078952-29$.

[2] S. Papadakis, "Evaluating a game-development approach to teach introductory programming concepts in secondary education,” Int. J. Technol. Enhanc. Learn., vol. 12, no. 2, pp. 127-145, 2020. https://doi.org/10.1504/ijtel.2020.106282

[3] E. Fokides and A. Mastrokoukou, "Results from a study for teaching human body systems to primary school students using tablets," Contemp. Educ. Technol., vol. 9, no. 2, pp. 154170, 2018, https://doi.org/10.30935/cet.414808

[4] C. F. Mang and L. J. Wardley, "Student Perceptions of Using Tablet Technology in PostSecondary Classes / Perceptions des étudiants quant à l'utilisation des tablettes électroniques dans les classes universitaires," Can. J. Learn. Technol. / La Rev. Can. l'apprentissage la Technol., vol. 39, no. 4, 2013, https://doi.org/10.21432/t22010

[5] M. Sarrab and L. Elgamel, "M Obile L Earning (M-L Earning) and," Int. J. Distrib. Parallel Syst., vol. 3, no. 4, pp. 31-39, 2013, doi: 10.3991/ijim. v3i4.986.

[6] I. Sural, "Augmented reality experience: Initial perceptions of higher education students," Int. J. Instr., vol. 11, no. 4, pp. 565-576, 2018, doi: 10.12973/iji.2018.11435a.

[7] S. Singhal, S. Bagga, P. Goyal, and V. Saxena, "Augmented Chemistry: Interactive Education System,” Int. J. Comput. Appl., vol. 49, no. 15, pp. 1-5, 2012, doi: 10.5120/77001041. https://doi.org/10.5120/7700-1041

[8] Y. Lai and J. Hsu, "Development trend analysis of augmented reality system in educational applications," in International Conference on Electrical and Control Engineering, 2011, pp. 6527-6531. https://doi.org/10.1109/iceceng.2011.6056941

[9] C. Arth, R. Grasset, L. Gruber, T. Langlotz, A. Mulloni, and D. Wagner, "The History of Mobile Augmented Reality,” no. June, 2015, [Online]. Available: http://arxiv.org/abs/1505. 01319.

[10] A. Buchori, P. Setyosari, I. Wayan Dasna, and S. Ulfa, "Developing character building learning model using mobile augmented reality on elementary school student in Central Java," Glob. J. Pure Appl. Math., vol. 12, no. 4, pp. 3433-3444, 2016.

[11] C. Liu, S. Huot, J. Diehl, W. E. MacKay, and M. Beaudouin-Lafon, "Evaluating the benefits of real-time feedback in mobile Augmented Reality with hand-held devices," Conf. Hum. Factors Comput. Syst. - Proc., pp. 2973-2976, 2012, https://doi.org/10. $1145 / 2207676.2208706$.

[12] O. M. Aldalalah, Z. Ababneh, A. Bawaneh, and W. Alzubi, "Effect of Augmented Reality and Simulation on the Achievement of Mathematics and Visual Thinking Among Students," Int. J. Emerg. Technol. Learn., vol. 14, no. 18, p. 164, 2019, https://doi.org/10. 3991/ijet.v14i18.10748

[13] L. Barnard, V. Paton, and W. Lan, "Online Self-Regulatory Learning Behaviors as a Mediator in the Relationship between Online Course Perceptions with Achievement," Int. Rev. Res. Open Distance Learn., vol. 9, no. 2, pp. 1-11, 2008. https://doi.org/10. 19173/irrodl.v9i2.516

[14] C. S. Carver and M. F. Scheier, Attention and Self-regulation: A Control-Theory Approach to Human Behavior. 2012.

[15] Y. Wang, G. Vincenti, J. Braman, and A. Dudley, "The ARICE framework: Augmented reality in computing education,” Int. J. Emerg. Technol. Learn., vol. 8, no. 6, pp. 27-34, 2013, https://doi.org/10.19173/irrodl.v9i2.516 
[16] R. Azuma, Y. Baillot, R. Behringer, S. Feiner, S. Julier, and B. MacIntyre, "Recent advances in augmented reality,” Int. J. Recent Technol. Eng., vol. 3878, no. 3, p. 462021, 2019. https://doi.org/10.1109/38.963459

[17] S. Cai, X. Wang, and F. K. Chiang, "A case study of Augmented Reality simulation system application in a chemistry course (Comput. Hum. Behav (2014):37(31-40))," Comput. Human Behav., vol. 39, p. 424, 2014, https://doi.org/10.1016/j.chb.2014.06.014

[18] R. Ashford, "QR codes and academic libraries," Coll. Res. Libr. News, vol. 71, no. 10, pp. 526-530, 2010, https://doi.org/10.5860/crln.71.10.8454.

[19] M. Santoso and L. B. Gook, "ARobot: development of 3rd person shooting game and handheld augmented reality," 2012. https://doi.org/10.1145/2407516.2407532

[20] N. Salkind, Exploring Research. 6th Edition. Prince-Hall, Upper Saddle River, 2006.

[21] D. F. O. Onah and J. E. Sinclair, "Assessing Self-Regulation of Learning Dimensions in a Stand-alone MOOC Platform," Int. J. Eng. Pedagog., vol. 7, no. 2, p. 4, 2017, https://doi.org/10.3991/ijep.v7i2.6511

[22] E. Ingleby, "Research methods in education," Prof. Dev. Educ., vol. 38, no. 3, pp. 507-509, 2012, doi: $10.1080 / 19415257.2011 .643130$.

[23] M. Kalogiannakis and S. Papadakis, "Evaluating a course for teaching introductory programming with Scratch to pre-service kindergarten teachers," Int. J. Technol. Enhanc. Learn., vol. 11, no. 3, p. 231, 2019, https://doi.org/10.1504/ijtel.2019.100478.

[24] J. Buchner and J. Zumbach, "Promoting intrinsic motivation with a mobile augmented reality learning environment," Proc. 14th Int. Conf. Mob. Learn. 2018, ML 2018, no. 1997, pp. 55-61, 2018.

[25] T. Hiranyachattada and K. Kusirirat, "Using mobile augmented reality to enhancing students' conceptual understanding of physically-based rendering in 3D animation," Eur. J. Sci. Math. Educ., vol. 8, no. 1, pp. 1-5, 2020.

[26] F. Ozdamli and C. Hursen, "An emerging technology: Augmented reality to promote learning," Int. J. Emerg. Technol. Learn., vol. 12, no. 11, pp. 121-137, 2017, doi: https://doi.org/10.3991/ijet.v12i11.7354

[27] V. Tugun, "Validity and reliability dissertation of the scale used for determination of perceptions and attitudes of teacher's proficiency in tablet pc-supported education," no. August, 2016, https://doi.org/10.18844/cjes.v11i2.617

[28] K. A. Mills and V. Chandra, "Microblogging as a literacy practice for educational communities," J. Adolesc. Adult Lit., vol. 55, no. 1, pp. 35-45, 2011, doi: 10.1598/JAAL.55.1.4.

[29] J. Underwood and G. Dillon, "Chasing dreams and recognising realities: Teachers' responses to ICT,” Technol. Pedagog. Educ., vol. 20, no. 3, pp. 317-330, 2011, https://doi.org/10.1080/1475939x.2011.610932

[30] S. Papadakis, M. Kalogiannakis, and N. Zaranis, "The effectiveness of computer and tablet assisted intervention in early childhood students' understanding of numbers. An empirical study conducted in Greece," Educ. Inf. Technol., vol. 23, no. 5, pp. 1849-1871, 2018, https://doi.org/10.1007/s10639-018-9693-7

[31] N. A. Albelbisi and F. D. Yusop, "Factors Influencing Learners' Self -Regulated Learning Skills in a Massive Open Online Course (MOOC) Environment," Turkish Online J. Distance Educ., no. July, pp. 1-16, 2019, https://doi.org/10.17718/tojde.598191

[32] R. F. Kizilcec, M. Pérez-Sanagustín, and J. J. Maldonado, "Recommending self-regulated learning strategies does not improve performance in a MOOC," L@S 2016 - Proc. 3rd 2016 ACM Conf. Learn. Scale, pp. 101-104, 2016, https://doi.org/10.1145/2876034. $\underline{2893378}$ 
[33] A. Littlejohn, N. Hood, C. Milligan, and P. Mustain, "Learning in MOOCs: Motivations and self-regulated learning in MOOCs," Internet High. Educ., vol. 29, 2015. https://doi.org/10.1016/j.iheduc.2015.12.003

[34] . Barnard-brak, W. Y. Lan, and V. O. Paton, "Learning Environment Self-Regulated Learning,” Int. Rev. Res. Open Distance Learn., vol. 11, no. 1, pp. 61-80, 2010. https://doi.org/10.19173/irrodl.v11i1.769

[35] M.-H. Cho and D. Shen, "Self-regulation in online learning," Distance Educ., vol. 34, no. 3, pp. 290-301, 2013.

[36] J. You and M. Kang, "The role of academic emotions in the relationship between perceived academic control and self-regulated learning in online learning," Comput. Educ., vol. 77, pp. 125-133, 2014. https://doi.org/10.1016/j.compedu.2014.04.018

\section{Authors}

Chusnul Muali is a doctorate student of Universitas Negeri Malang, Malang, Indonesia. He is currently teaching at the Universitas Nurul Jadid, Probolinggo, Indonesia. His research interests are instructional technology, mobile learning, elearning, and multimedia learning. chusnulmuali@unuja.ac.id.

Punaji Setyosari is a professor in Instructional Technology, Department of Educational Technology, Faculty of Education, Universitas Negeri Malang. His research interests include research on Instructional technology and media, teaching assessment, and instructional and learning strategies.

Purnomo is a lecturer at Malang State University, Faculty of Engineering. He graduated with an education degree in 1983 and graduated with an engineering degree in 1998. In 1991 he graduated with a master's degree in education. In 2014, he graduated with a doctorate in education from Yogyakarta State University. Affiliation: Universitas Negeri Malang.

Lia Yuliati is a lecturer in the Department of Physics, Universitas Negeri Malang, Indonesia. Her research interests include mobile learning, instructional media, and learning engineering.

Article submitted 2020-06-19. Resubmitted 2020-08-08. Final acceptance 2020-08-08. Final version published as submitted by the authors 